\title{
(C) OPEN ACCESS \\ Burn aggravated infected wart in a patient with type 2 diabetes: a medical challenge
}

\author{
Tahseen Ahmed Khan, ${ }^{1}$ Mahmood Sheikh, ${ }^{2}$ Iqbal Azher, ${ }^{2}$ Abdul Khaliq Sheikh ${ }^{3}$
}

'Department of Diabetology, Indus Hospital, Karachi, Pakistan ${ }^{2}$ Department of Pharmacognosy, University of Karachi, Karachi, Pakistan

${ }^{3}$ Department of Pharmaceutics, Hamdard University, Karachi, Pakistan

\section{Correspondence to}

Dr Tahseen Ahmed Khan, tahseen.ahmed@hotmail.com

Accepted 14 February 2018

Check for updates

To cite: Ahmed Khan T, Sheikh M, Azher I, et al. BMJ Case Rep Published Online First: [please include Day Month Year]. doi:10.1136/ bcr-2017-222897

\section{SUMMARY}

An infectious wart of foot in a patient with diabetics is a medical challenge, and it gets worse when aggravated with burns. We present a case of a 67-year-old Pakistani man, diabetic for 20 years presented at our healthcare centre. While awaiting his culture sensitivity report, he was prescribed an empiric antibiotic therapy. Patient then travelled to Saudi Arabia for pilgrimage 3 days later with growth of Staphylococcus aureus and Proteus species in culture and sensitivity report; during his travel, he walked barefoot and the infected wart aggravated with severe burn. Patient continued empiric treatment for 14 days. On his arrival, infected wart worsened with dead burnt skin, heavy purulent discharge on plantar region. $X$-rays revealed marked arthritic changes. Cefepime $500 \mathrm{mg}$ three times a day intravenously was initiated following wound debridement. Patient was switched to moxifloxacin $400 \mathrm{mg}$ once daily postoperatively for 7 days until completely healed.

\section{BACKGROUND}

Diabetic foot ulcer affects 4 million people annually across the globe. About 70 out of 100 patients undergoing lower limb amputation are diabetic. The annual incidence of diabetic foot ulcer ranges between 1.0 and $2.0 \%$. Prevalence of foot ulcers is reported between $5.3 \%$ and $10.5 \%$ and lifetime risk diabetic foot ulcer is $25 \% .^{1}$ Burn injury in patients with diabetes has been a current subject of interest in published research studies. Past studies have confirmed increased complication in patients with diabetes contrasted with patients without diabetes who have sustained these injuries. Very little research has been done to foot-particular diabetic burn injury. ${ }^{2}$ Thermal injury is one of the precipitating events associated with diabetic foot ulcers. In patients with diabetes, it has always been a challenge for healthcare professionals to treat diabetic foot infections, including lesions, wounds and scars, especially if the patient has other deformities. Diabetes in combination with a foot burn can intensify the complications in wound healing; however, the effect of diabetes on results of patients with foot burn has not been analysed. ${ }^{3}$ In this particular case study, multiple issues like burnt feet with infected wart was addressed by prescribing the right treatment option and wound care techniques which prevented the leg from amputation. We were able to successfully treat the subject and set an example of diabetic foot care preventing the leg from amputation.

\section{CASE PRESENTATION}

A 67-year-old Pakistani man diagnosed with type II diabetes since 20 years. His family history included, type II diabetic father and elder brother. Currently, the patient is taking human insulin (soluble insulin 30\% and isophane insulin 70\%). He presented with an infectious wart on plantar surface on his right foot. The sample from the infection site was sent for microbiological evaluation and sensitivity, while he was prescribed amoxicillin/clavulanate potassium $1 \mathrm{~g}$ twice daily for 7 days. Three days later patient travelled to Saudi Arabia (KSA) to perform pilgrimage without consultation and sharing his culture report. During his stay, he suffered severe burns on the plantar surfaces of both the feet while walking barefoot. Followed by, a watery discharge from blisters, the debilitated patient contacted us and was advised to continue treatment and immediately visit a nearby healthcare centre for further medical advice. He received the first aid from a healthcare centre in KSA after 2 days of the incident and was further prescribed oral paracetamol $500 \mathrm{mg}$ three times a day and fusidic acid cream twice daily for local application. After spending about 2 weeks in KSA, patient travelled back to Pakistan and visited our healthcare centre. On examination, we found infected wart, aggravated with dead burnt skin on the plantar surfaces of both the feet with heavy purulent discharge (figure 1).

\section{INVESTIGATIONS}

Microbial culture of the infected wart was sent to the laboratory to identify the causative organisms and their susceptibility (table 1 ).
Gram stain
- Pus cells: $(++)$
- epithelial cells: $(+)$
- gram positive cocci: (moderate to numerous)
- gram Negative rods: (moderate).

\section{Results}

- Organism 1 (heavy growth of Staphylococcus aureus)

- organism 2 (heavy growth of Proteus species). $\mathrm{X}$-rays of both feet showed the marked erosive changes at the tarsometatarsal joint of the big toe, plantar calcaneal spur, soft tissue swelling and irregularity was seen at the plantar aspect of left foot suggestive of diabetic foot (figure 2). 


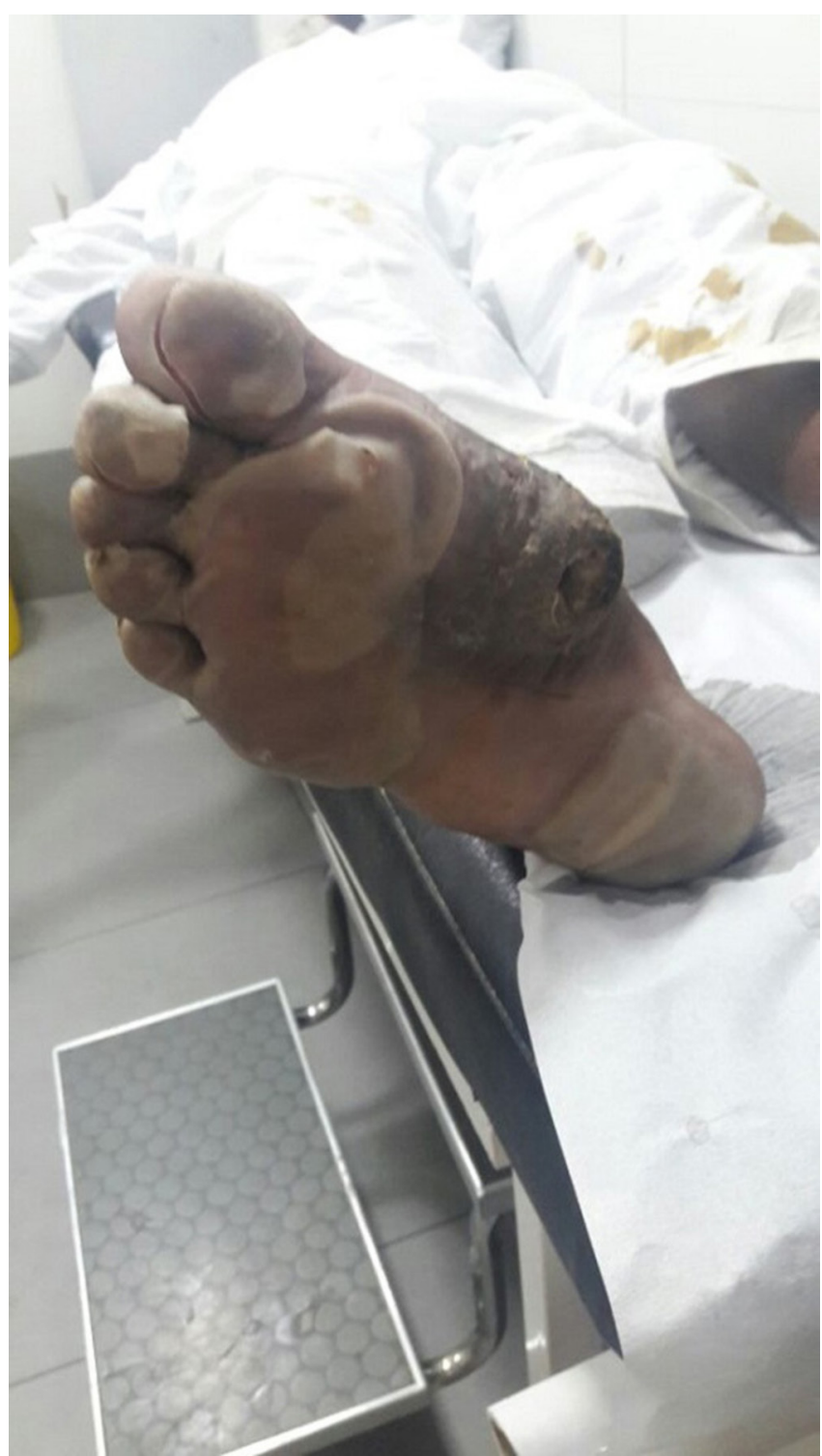

Figure 1 Infected wart and burnt skin.

\section{DIFFERENTIAL DIAGNOSIS}

Cellulitis.

Peripheral diabetic neuropathic ulcer.

Squamous cell carcinoma.

\begin{tabular}{llllll}
\hline \multicolumn{2}{l}{ Table 1 } & \multicolumn{5}{c}{ Sensitivity/susceptibility patterns for identified organisms } \\
\hline Antibiotic & Strain 1 & Strain 2 & Antibiotic & Strain 1 & Strain 2 \\
\hline Amox-Clav & & $\mathrm{S}$ & Gentamicin & $\mathrm{S}$ & $\mathrm{S}$ \\
Amikacin & $\mathrm{S}$ & $\mathrm{S}$ & Aztreonam & & $\mathrm{S}$ \\
Chloramphenicol & $\mathrm{S}$ & & Imipenem & & $\mathrm{S}$ \\
Vancomycin & $\mathrm{S}$ & & Ampicillin & & $\mathrm{R}$ \\
Co-trimoxazole & $\mathrm{S}$ & $\mathrm{S}$ & Ciprofloxacin & $\mathrm{R}$ & $\mathrm{S}$ \\
Tazobactam & $\mathrm{S}$ & $\mathrm{S}$ & Fusidic acid & $\mathrm{R}$ & \\
Penicillin & $\mathrm{R}$ & & Cefuroxime & & $\mathrm{R}$ \\
Ceftriaxone & $\mathrm{R}$ & $\mathrm{S}$ & Cefixime & $\mathrm{R}$ & $\mathrm{R}$ \\
Erythromycin & $\mathrm{R}$ & & Clindamycin & $\mathrm{S}$ & \\
Cefoxitin & $\mathrm{R}$ & & Tetracycline & $\mathrm{R}$ & \\
\hline
\end{tabular}

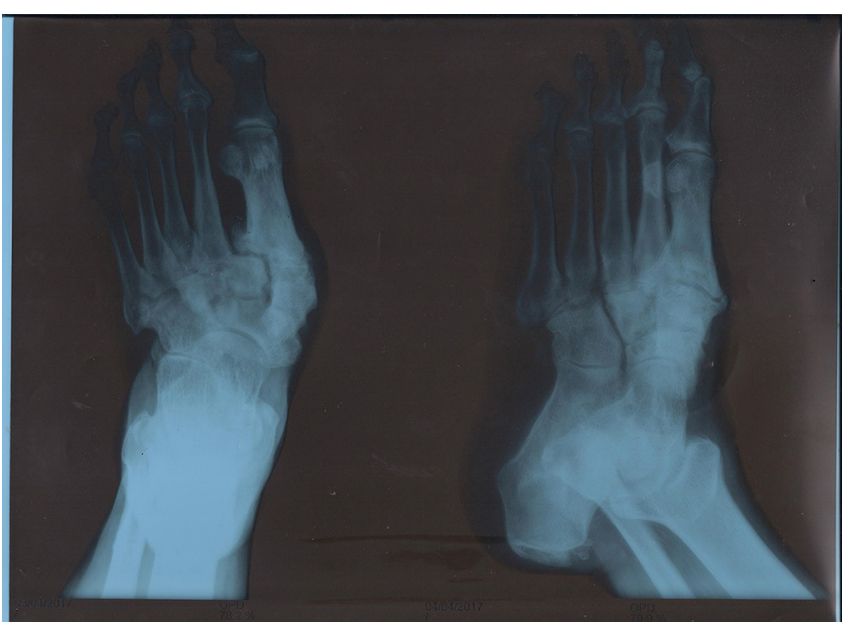

Figure 2 X-ray of feet.

\section{TREATMENT}

Cefepime $500 \mathrm{mg}$ three times a day intravenously was started along with wound debridement. Dead skin was removed (figure 3) after 3 days of starting intravenous cefepime and wound was bandaged with a povidone iodine $10 \%$ solution diluted 1:1 with sterile normal saline solution. Cefepime was stopped after 13th day of the treatment and the patient was switched to oral moxifloxacin $400 \mathrm{mg}$ once daily for 7 days as maintenance therapy. Bacteriostatic gauze dressing was periodically applied until the wound was completely healed (figure 4).

\section{OUTCOME AND FOLLOW-UP}

The patient recovered well following antibiotic treatment with coverage for identified bacterial species; dead tissue was removed and was periodically dressed, granulation of nearly skin completed and the patient was taken out of a situation where amputation seemed the only management option.

\section{DISCUSSION}

We looked for the similar cases in NCBI and NLM databases; we did not find cases where burns aggravated a previously infected wart in patients with diabetes. A resembling case reported by Valdeset, ${ }^{4}$ in which the patient suffered burn wounds while walking in the sand. Another similar case was the case of Putz et al. ${ }^{5}$ Burnt foot cases from such an unusual heat sources are those cited by Abu-Qamar, ${ }^{6}$ in patients with diabetes who never recognised religious customs as risk factors and suffered burns. We also referred to Al-Qattan, ${ }^{7}$ where 12 patients have been

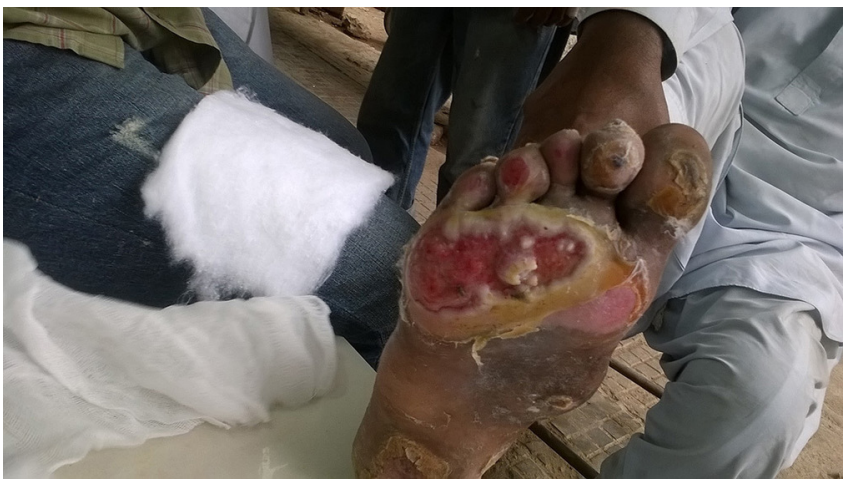

Figure 3 Removal of dead skin. 


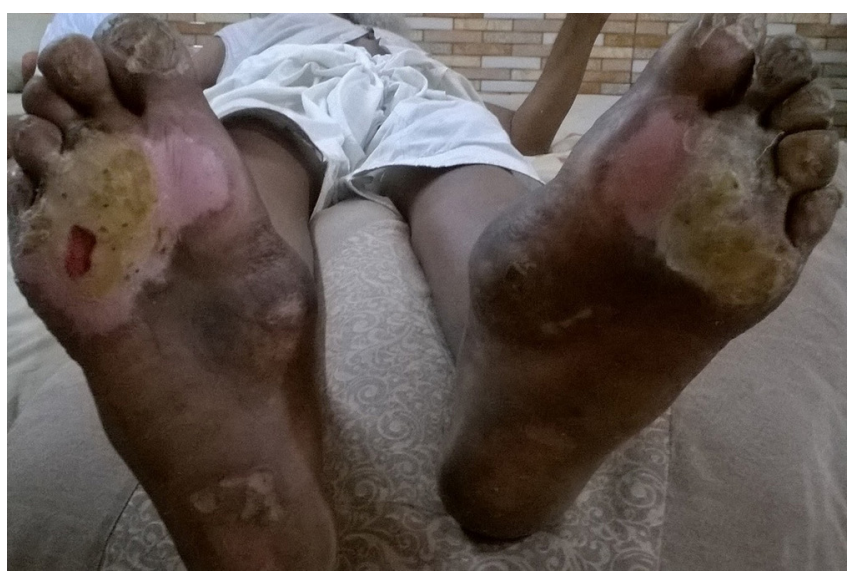

Figure 4 Wound healing.

reported where burns resulted while performing barefoot rituals during pilgrimage.

An infectious wart on foot of a patient with diabetes that looked treatable with antibiotics, within no time turned into a medical challenge where we started considering amputation as a management option. Nevertheless, we decided another round of extended spectrum antibiotic before suggesting amputation as last resort for the patient. Ignorance and lack of compliance by patient to travel abroad without medical consultation on culture

\section{Patient's perspective}

When I suffered these severe burns, I was really afraid of the consequences of leg amputation. Since I was out of country, I felt that I will not be able to get proper treatment which further added to my fear and I got panic. I believe the biggest mistake I made was my decision to walk bare foot to the hotel without foreseeing the consequences. I would like to advise all patients with type 2 diabetes to consult their treating physician prior to their travel.

\section{Learning points}

Diabetic foot is a common complication of diabetes mellitus.

- Patients should have perpetual counselling about foot care and the consequences of ignorance.

- Any injury or wound must be taken seriously in patients with diabetess patients.

- Patients with diabetes should avoid walking barefoot.

- Patient at high risk of developing ulcer must be referred to a Podiatrist for footwear specifically designed to reduce pressure while walking in these patients. report made an infectious wart to a condition demanded immediate surgery.

Educating patients to avoid heat sources and warning them about the risks and consequences of walking barefoot may help in this situation. Also, it is suggested to refer these patients to a Podiatrist for his recommendations on specialised footwear for these patients that can help reduce pressure, friction and heat. Economically and culturally this can be a challenge too in the society in this part of the world considering the health economic burden on individual that pay out of their pockets for healthcare.

Besides, patient should be routinely monitored for the glycaemic levels and there HbA1C should be checked to ensure diabetic control in these patients. There have been cases reported in literature where poor glycaemic controls in elderly patients, who developed diabetic polyneuropathy are at risk of developing these warts/ulcers and subsequent infections that lead to preventable amputation. This case can be bench marked for management of such infectious warts that are aggravated with burns, showing mixed culture of gram positive cocci and gram negative rods treated successfully with fourth generation cephalosporin followed by oral moxifloxacin with similar coverage before considering incapacitating surgeries.

Contributors TAK contributed to the concept, design, planning and conduct of this case study. MS contributed as a study coordinator for this case study. IA contributed for the analysis of data and its interpretation. AKS contributed for writing the manuscript.

Funding This research received no specific grant from any funding agency in the public, commercial or not-for-profit sectors.

Competing interests None declared.

\section{Patient consent Obtained.}

Provenance and peer review Not commissioned; externally peer reviewed.

Open Access This is an Open Access article distributed in accordance with the Creative Commons Attribution Non Commercial (CC BY-NC 4.0) license, which permits others to distribute, remix, adapt, build upon this work non-commercially, and license their derivative works on different terms, provided the original work is properly cited and the use is non-commercial. See: http://creativecommons.org/ licenses/by-nc/4.0/

(C) BMJ Publishing Group Ltd (unless otherwise stated in the text of the article) 2018. All rights reserved. No commercial use is permitted unless otherwise expressly granted.

\section{REFERENCES}

1 Basit A, Hydrie MZ, Hakeem R, et al. Frequency of chronic complications of type II diabetes. J Coll Physicians Surg Pak 2004;14:79-83.

2 Nerone VS, Springer KD, Atway SA. Diabetic foot burns: a case series. J Foot Ankle Surg 2014;53:453-5.

3 WHO. About diabetes [Internet]. Geneva: WHO.

4 Gaztelu Valdés V, Gago Fornells M, Garcia González RF, et al. Hot sand burns on the sole of a patient with diabetes. J Wound Care 2002;11:170-1.

5 Putz Z, Nadas J, Jermendy G. Severe but preventable foot burn injury in diabetic patients with peripheral neuropathy. Med Sci Monit 2008;14:CS89-91.

6 Abu-Qamar MZ, Wilson A. The lived experience of a foot burn injury from the perspective of seven Jordanians with diabetes: a hermeneutic phenomenological study. Int Wound J 2012;9:33-43.

7 Al-Qattan MM. The "Friday Mass" burns of the feet in Saudi Arabia. Burns 2000;26:102-5. 
Copyright 2018 BMJ Publishing Group. All rights reserved. For permission to reuse any of this content visit http://group.bmj.com/group/rights-licensing/permissions.

BMJ Case Report Fellows may re-use this article for personal use and teaching without any further permission.

Become a Fellow of BMJ Case Reports today and you can:

- Submit as many cases as you like

- Enjoy fast sympathetic peer review and rapid publication of accepted articles

- Access all the published articles

- Re-use any of the published material for personal use and teaching without further permission

For information on Institutional Fellowships contact consortiasales@bmjgroup.com

Visit casereports.bmj.com for more articles like this and to become a Fellow 